Canadian Science Publishing

Canadian Journal of Earth Sciences Revue canadienne des sciences de la Terre

\title{
Age and origin of the Cannon Point syenite, Essex County, New York: Southernmost expression of Monteregian Hills magmatism?
}

\begin{tabular}{|r|l|}
\hline Journal: & Canadian Journal of Earth Sciences \\
\hline Manuscript ID & cjes-2016-0144.R1 \\
\hline Manuscript Type: & Article \\
\hline Date Submitted by the Author: & 31 -Oct-2016 \\
\hline Kemplete List of Authors: & $\begin{array}{l}\text { Bailey, David; Hamilton College, Geosciences } \\
\text { Lupulescu, Marian; New York State Museum } \\
\text { Chiarenzelli, Jeffrey; St Lawrence University, Geology } \\
\text { Traylor, Jonathan; Hamilton College, Geosciences }\end{array}$ \\
\hline \multicolumn{2}{|c}{ Mesozoic, geochronology, geochemistry, igneous rocks, New York } \\
\hline \multicolumn{2}{|l}{} \\
\hline
\end{tabular}

\section{SCHOLARONE \\ Manuscripts}




\title{
Age and origin of the Cannon Point syenite,
}

Essex County, New York:

\section{Southernmost expression of Monteregian Hills}

\section{magmatism?}

\author{
David G. Bailey \\ Geosciences Dept., Hamilton College, Clinton, NY \\ 315-859-4142; dbailey@hamilton.edu \\ Marian Lupulescu \\ New York State Museum, Albany, NY \\ marian.lupulescu@nysed.gov \\ Jeffrey Chiarenzelli \\ St. Lawrence University, Canton, NY \\ jchiarenzelli@stlawu.edu \\ Jonathan P. Traylor \\ Hamilton College, Clinton, NY \\ jpspeeddemon@gmail.com
}




\begin{abstract}
Two syenite sills intrude the local Paleozoic strata of eastern New York State and are exposed along the western shore of Lake Champlain. The sills are fine-grained, alkali feldspar syenites and quartz syenites, with phenocrysts of sanidine and albite. The two sills are compositionally distinct, with crossing REE profiles and different incompatible element ratios, prohibiting a simple petrogenetic relationship. Zircon extracted from the upper sill yield a $\mathrm{U}-\mathrm{Pb}$ age of $131.1+/-1.7 \mathrm{Ma}$, making the sills the youngest known igneous rocks in New York State. This age is similar to the earliest intrusions in the Monteregian Hills of Quebec, over $100 \mathrm{~km}$ to the north. $\mathrm{Sr}$ and $\mathrm{Nd}$ radiogenic isotope ratios are also similar to those observed in some of the syenitic rocks of the eastern Monteregian Hills.

The Cannon Point syenites have compositions typical of A-type, within-plate granitoids. They exhibit unusually high $\mathrm{Ta}$ and $\mathrm{Nb}$ concentrations, resulting in distinct trace element signatures that are similar to silicic rocks of the Valles Caldera, a large, rift-related magmatic system. We suggest that the Cannon Point syenites were melts derived primarily by anatexis of old, primitive, lower crustal material in response to Mesozoic rifting and to the intrusion of mantle-derived magmas. The sills indicate that the effects of continental rifting were spatially and temporally extensive, resulting in the reactivation of basement faults in the Lake Champlain valley hundreds of kilometers west of the active rift boundary, and crustal melting over $50 \mathrm{Ma}$ after the initiation of rifting.
\end{abstract}

Keywords: Mesozoic, Igneous Rocks, New York, Geochronology, Geochemistry 


\section{Introduction}

Magmatic activity was compositionally diverse and geographically widespread across New England throughout the Mesozoic. Igneous rocks range in age from $\sim 240 \mathrm{Ma}$ to $\sim 85$ Ma (McHone and Butler 1984), and in composition from highly alkaline mafic intrusions (e.g. lamprophyres) to highly alkaline felsic intrusions (e.g. nepheline syenites and quartz syenites), to high silica granites (Eby 1985; McHone 1987). McHone and Butler (1984) identified and described four distinct igneous provinces in the region: 1) the Coastal New England Province, 2) the Eastern North America Dolerite Province, 3) the White Mountain Province, and 4) the New England - Quebec Province. Cannon Point lies on the western margin of all of this activity, within the broad New England - Quebec (NEQ) magmatic province (Figure 1). Magmatism in the western portion of the NEQ was dominated by mafic, alkaline intrusions, particularly in the Monteregian Hills region of southern Quebec (Eby 1987) and throughout the Lake Champlain valley (McHone 1987; McHone and McHone 1999). Silica-saturated magmas in this area are uncommon, unlike in the White Mountain province where they are dominant (Eby et al. 1992; Foland and Allen 1991). Other than the small $\left(<0.2 \mathrm{~km}^{2}\right)$ Barber Hill syenitic stock $\sim 5 \mathrm{~km}$ due east of Cannon Point in Charlotte, VT, the closest similar silicic intrusives are more than $100 \mathrm{~km}$ to the north at Mont Brome and Mont Shefford in the Monteregian Hills, or $>150 \mathrm{~km}$ to the east in the White Mountains of New Hampshire. Previously identified Mesozoic plutonic rocks in upstate New York are limited to small, but numerous kimberlitic dikes and diatremes (Bailey and Lupulescu 2015).

Mesozoic magmatism in the NEQ and in the WMMS provinces has been ascribed to two fundamentally different tectonic mechanisms: 1) asthenospheric mantle plume-derived melts related to the Great Meteor Hotspot (Crough 1981; Heaman and Kjarsgaard 2000), or 2) 
lithospheric mantle derived melts generated in response to Mesozoic rifting and crustal thinning (McHone and Butler 1984; Parrish and Lavin 1982; Roulleau and Stevenson 2013). The purpose of this study is to provide additional constraints on the timing and nature of Mesozoic magmatism in northeastern North America by obtaining age and geochemical data for the poorly known intrusions at Cannon Point.

\section{Previous Studies, Field Relations, and Petrography}

The Cannon Point intrusions are exposed along the western shore of Lake Champlain in northern New York over a distance of $\sim 1.5 \mathrm{~km}$ (Figure 1). The sills were first recognized and mapped by Buddington and Whitcomb (1941), but the only subsequent work done on these intrusions was by three Middlebury College students over 30 years ago (Beyer 1971; Conard 1983; Crocker 1971). While initially thought to be lava flows (Beyer, 1971), field relations clearly reveal that there are at least two sills that intrude the local dark gray, shaly limestones of the Middle Ordovician Trenton Group (Conard 1983) (Figure 2). Both sills exhibit $\sim 25 \mathrm{~cm}$ thick chilled margins where in contact with the limestone, and the thickness of the limestone between the two sills varies from 2 to $50 \mathrm{~cm}$. The two sills each have a minimum thickness of $5 \mathrm{~m}$; there are no exposures that show a complete vertical section through either sill.

Both sills are porpyyritic, with glomerocrysts of feldspar present in nearly all samples; this texture is best observed in the finer-grained chilled margins of the intrusions. The feldspar phenocrysts are sub- to euhedral, 1-5 mm in length, and comprise 2-25 modal percent of individual hand samples. Phenocrysts of both albite and sanidine are present, with sanidine comprising $>90 \%$ of the phenocryst assemblage. The sanidine phenocrysts exhibit 
simple Carlsbad twins (Figure 3), are microperthitic, have poorly developed Rapakivi texture, and are moderately to extensively altered, being replaced by sericite and calcite. SEM/EDS analysis of the phenocrysts reveals that they are fairly homogeneous, with compositions averaging $\sim$ Or $80+/-5$; albitic rims on the sanidine as well as the albite phenocrysts have compositions $\sim$ Ab $92+/-5$. No other phenocryst phases were observed, although sparse 0.5 - $1 \mathrm{~mm}$ long aggregates of secondary minerals (calcite, titanite, rutile, synchesite, and pyrite) exhibit shapes that suggest they may be pseudomorphs after amphibole.

Groundmass textures range from spherulitc, to trachytic, to hypidiomorphic granular, to granophyric - generally related to the distance from a chilled margin. Groundmass phases identified, in order of decreasing abundance, are alkali feldspar, albite, quartz, magnetite, and zircon. All of the rocks have been altered, some quite extensively. This is evidenced by the ubiquitous sericitization of the feldspars, and the carbonatization of many samples.

\section{Methods}

Thirteen hand samples were collected from exposures on the western shore of Lake Champlain just south of the town of Essex, NY. Two thin sections were prepared from each hand sample for petrographic and SEM/EDS analysis.

All thirteen samples were prepared for whole-rock geochemical analysis. The hand samples were crushed in a hardened steel jaw crusher, and then pulverized to a fine powder using a tungsten carbide ring mill. Rock powders were sent to the Geoanalytical Laboratory at Washington State University (WSU) for major and trace element analysis by X-Ray Fluorescence (XRF) spectrometry. The samples were analyzed on an automated Thermo- 
ARL XRF spectrometer using 40 international standards for calibration. Splits of the rock powders were also sent to Washington State University for rare earth and additional trace element analyses by inductively coupled plasma mass spectrometry (ICP-MS). Detailed sample preparation protocols, analytical methods, and estimates of analytical precision and accuracy are available at http://soe.wsu.edu/facilities/geolab/technotes/.

Three whole-rock samples were selected for $\mathrm{Sr}$ and $\mathrm{Nd}$ isotope analyses at the Isotope Geology and Geochronology Research Facility at Carleton University, Ottawa, Ontario. Two of the least altered samples, one from each sill, along with one of the most altered samples (based upon petrographic and geochemical criteria discussed below) were selected for isotopic analysis. Detailed analytical methods are described in Cousens et al. (2008).

One large rock sample was sent to the Arizona Laserchron Center at the University of Arizona for radiometric dating. Over 100 zircons were extracted from the sample by traditional methods of crushing and grinding, followed by separation with a Wilfley table, heavy liquids, and a Frantz magnetic separator. Selected zircon grains were incorporated into a 1" diameter epoxy mount; the grains were ground to approximately half-thickness, polished, imaged with cathodoluminescence, and cleaned prior to isotopic analysis. U-Pb geochronology of the zircons was conducted by laser ablation multicollector inductively coupled plasma mass spectrometry (LA-MC-ICPMS). Detailed analytical methods and estimates of analytical precision and accuracy are provided in Gehrels et al. (2008) and in Appendix 1. 


\section{Results}

Whole-Rock Geochemistry

On the basis of modal mineralogy, the coarser-grained samples have compositions that cluster around the quartz syenite field on the IUGS QAPF diagram. Because the majority of the samples are extremely fine-grained, it is easier to represent their compositions on the total alkali versus silica diagram (Figure 4), on which data from the Cannon Point sills plot in the trachyte and rhyolite compositional fields. The two sills are chemically distinct, with the lower sill having relatively lower silica and higher total alkali contents, as well as higher $\mathrm{La} / \mathrm{Sm}$ and $\mathrm{Ce} / \mathrm{Ta}$ ratios (Table 1; Figures 4 and 5). While the two sills have mineralogies and bulk compositions similar to some of the syenitic units in the White Mountains and in the Monteregian Hills (Fig. 4), their trace element characteristics are distinct (Fig. 5).

Like most alkaline granitoids, both sills have relatively elevated REE concentrations and pronounced negative europium anomalies, probably reflecting fractionation of alkali feldspar (Leeman and Phelps 1981) (Fig. 6a). The higher silica and generally more evolved upper sill has a lower LREE concentration than the lower sill, more chemical variability, less steep LREE trends, a more pronounced negative europium anomaly, and a flatter overall REE profile.

\section{Zircon Geochronology}

Zircon is a minor groundmass phase in the coarser-grained sill interiors; it rarely exceeds 100 microns in length. Nine grains extracted from the upper sill were analyzed for trace element composition by LA-ICPMS at Rensselaer Polytechnic Institute. The zircons are uniform in composition, being strongly enriched in the HREE and having pronounced 
positive cerium anomalies and only minor negative europium anomalies (Fig. 6b), typical of magmatic zircons from syenitic rocks (Belousova et al. 2002).

Twenty-nine zircon grains from the upper sill dated using LA-MC-ICPMS at the Arizona Laserchron Center yielded concordant U-Pb ages (Table 2). The weighted mean age of the data is $131+/-1.7 \mathrm{Ma}(\mathrm{MSWD}=0.36$; Prob $=0.99)($ Figure 7$)$, which is interpreted as the time of emplacement and crystallization of the sill. This age is broadly consistent with the measured ages of other igneous rocks in the Monteregian Hills province that range between 108 and $149 \mathrm{Ma}$ (Figure 8), although some researchers have argued that most of the plutons in the Monteregian Hills were intruded over a very short time interval of $123.5+/-1 \mathrm{Ma}$ (Eby 2006; Foland et al. 1986). Eby (1987) noted that rocks in the Monteregian Hills fall into two groups: a younger and volumetrically dominant group of highly undersaturated rocks with ages between 118-122 Ma, and an older group with ages between 130-140 Ma which contains slightly undersaturated to silica-saturated rock compositions. The Cannon Point quartz syenites clearly fit into this older group. The nearby Barber Hill syenite in Vermont has, in the past, been associated with the Cannon Point syenite based upon their close proximity (McHone 1987), although their measured ages differ by $20 \mathrm{Ma}$ (Figure 8). The age on the Barber Hill syenite of $111+/-2$ Ma (Armstrong and Stump 1971) is a K-Ar date on “slightly altered biotite" and, as pointed out by McHone (1987), is very likely too young due to either argon loss or being a cooling age.

Magmatism in the White Mountain Magma Series (WMMS) occurred over a wider time span, from $\sim 200-100 \mathrm{Ma}$, but with two apparent episodes of increased activity: one at $\sim 180$ Ma, and the other at $\sim 120 \mathrm{Ma}$ (Foland and Faul 1977). Hubacher and Foland (1991) argued that the younger WMMS intrusions of northern New England intruded over a very short time 
interval of $122.5+/-1 \mathrm{Ma}$, essentially synchronous with the main episode of magmatism in the Monteregian Hills. The main difference between Monteregian Hills magmatism and the younger White Mountain magmatism is the predominance of undersaturated rocks in the Monteregian Hills province, and of silica-saturated rocks in the younger WMMS province (Eby 1987). The Cannon point syenites clearly are part of the widespread episode of early Cretaceous magmatism in the New England - Quebec province with similarities to syenitic units in both the Monteregian Hills and in the younger WMMS. They are, however, spatially removed from the main areas of magmatic activity, and are some of the older syenitic rocks of the early Cretaceous episode of igneous activity in the region.

\section{Radiogenic Isotope Ratios}

Three whole-rock samples were selected for $\mathrm{Sr}$ and $\mathrm{Nd}$ isotope analysis; one from each of the two sills, and the third from one of the most extensively altered samples in order to evaluate the effects of the metasomatic alteration on the two isotope systems. Because sericitization and carbonatization were the two visually observed styles of alteration, and the secondary phases produced are volatile-bearing, we used the loss on ignition as a proxy for the degree of alteration. The most apparent chemical effect of alteration is an increase in the amount of calcium, which is positively correlated with the loss on ignition values (Figure 9a). Not surprisingly, Sr concentrations also appear to have been affected by the alteration processes (Figure 9b). Two samples with the lowest LOI and $\mathrm{CaO}$ concentrations, one from each sill, were selected for isotopic analysis. Additionally, the most altered sample was also analyzed in order to provide information on the effects of alteration on the two isotopic systems. All three samples yielded unusual and nearly identical isotopic ratios, with 
relatively high ${ }^{87} \mathrm{Sr} /{ }^{86} \mathrm{Sr}_{\mathrm{i}}$ (Figure 10). Some syenitic rocks from the eastern Monteregian complexes (i.e. Mt. Brome and Shefford) have similar isotopic compositions, which Landoll and Foland (1996) interpreted as being the result of assimilation-fractional crystallization processes. However, because of the low (36-200 ppm) Sr concentrations in the Cannon Point samples, and because all of the samples have clearly experienced hydrothermal alteration, we interpret the data to indicate a complete resetting of the $\mathrm{Sr}$ isotope ratios, probably reflecting input of Sr from the surrounding Ordovician limestones.

\section{Discussion}

Mesozoic magmatism in northeastern North America began at approximately 200 Ma with voluminous flood basalt volcanism related to continental rifting and the opening of the Atlantic (McHone 2012; McHone et al. 2014; Schlische et al. 2003). Post-Circum-Atlantic Magmatic Province (CAMP) activity was widely distributed, both geographically and temporally, and was compositionally diverse. Two areas of concentrated igneous activity were in the White Mountains of central and northern New Hampshire, and in the Monteregian Hills of southern Quebec. In the White Mountains, there were two pronounced periods of activity (one $\sim 180 \mathrm{Ma}$ and a second $\sim 125 \mathrm{Ma}$ ) that generated large volumes of predominantly silica-saturated melts (e.g. diorites, granites, and syenites). In the Monteregian Hills, most of the igneous activity was $\sim 125 \mathrm{Ma}$, and was dominated by silicaundersaturated melts (e.g. ijolites, essexites, nepheline diorites, etc.). The localized, and relatively linear distribution of intrusions in both of these areas has been explained by the movement of the North American plate over a mantle hotspot (Crough 1981; Foland et al. 1986), or alternatively, by localization of magmas along ancient faults in the basement that 
were reactivated by Mesozoic rifting (McHone and Butler 1984; Roulleau and Stevenson 2013). Outside of these two areas, Mesozoic igneous activity was limited, represented primarily by small mafic alkaline dikes (McHone 1987) or small kimberlitic intrusions (Bailey and Lupulescu 2015). The two sills at Cannon Point are exceptions to this pattern, being relatively large syenite intrusions over $100 \mathrm{~km}$ south of the Monteregian Hills, and 150 km west of the WMMS. With an age of $131 \mathrm{Ma}$, they are also some of the oldest Cretaceous intrusions in the region.

The two sills have distinct chemical compositions, with the upper sill being more evolved relative to the lower sill (Figures 4-6). The dramatically different REE and incompatible element ratios in the two sills prohibit the upper sill from being derived by any simple fractionation process from the lower sill; the data are more consistent with an origin of each sill by different degrees of partial melting of a primitive, lower crustal source. The lack of any contemporaneous mafic magmas, along with the apparently modified radiogenic isotope ratios, make it difficult to construct a more detailed petrogenetic model for these syenites.

The Cannon Point syenites have bulk compositions and trace element concentrations typical of within-plate granitoids, and are similar to silicic rocks in the Monteregian Hills and the White Mountains (Figure 11). Their trace element profiles are distinct from granitoids from hot spot or subduction-related tectonic settings (e.g. lower $\mathrm{Ba} / \mathrm{Th}$ and higher $\mathrm{Nb} / \mathrm{Ce}$ ratios) (Figure 12a) but are, not surprisingly, similar to the trace element profiles of silicic rocks from the Monteregian Hills and the White Mountains (Figure 12b). One of the most notable features of these rocks is their unusually high $\mathrm{Ta}$ and $\mathrm{Nb}$ contents, which results in unusually low $\mathrm{Ba} / \mathrm{Ta}$ ratios, and correspondingly high $\mathrm{Nb} / \mathrm{Y}$ ratios (Figure $12 \mathrm{~b}$ ). The only other silicic igneous rocks that we have found with similar trace element characteristics are 
the tuffs and rhyolites from the Valles Caldera in New Mexico, which have been interpreted as melts of hybridized Precambrian crust generated within an incipient continental rift (Rowe et al. 2007). The occurrence of silicic igneous rocks with similar chemical characteristics within the Lake Champlain valley, which has been interpreted as part of a failed ancient continental rift (Burke 1977; McHone 1987), supports the interpretation that the Cannon Point magmas formed by partial melting of Precambrian basement rocks, and that these magmas then intruded along ancient faults reactivated by Mesozoic rifting.

\section{Conclusions}

With an emplacement age of $\sim 131+/-1.7 \mathrm{Ma}$, the syenitic intrusions at Cannon Point on the western shore of Lake Champlain are the youngest known igneous rocks in New York State. They are broadly similar in both age and chemical composition to intrusive rocks in the White Mountains of New Hampshire and the Monteregian Hills of Quebec, but they are over $100 \mathrm{~km}$ distant from either igneous province. We suggest that the Cannon Point magmas were generated in response to Mesozoic rifting and to the crustal intrusion of mantle-derived, alkaline magmas. The sills indicate that the effects of continental rifting were spatially and temporally extensive, resulting in the reactivation of basement faults in the Lake Champlain valley hundreds of kilometers west of the active rift boundary, and crustal melting over 50 Ma after the initiation of rifting.

\section{Acknowledgements}

The authors wish to thank the following people for their assistance on this project: Dave Tewksbury for preparing the regional map; Ken Bart for help with SEM/EDS mineral 
analysis; Rick Conrey for XRF data and for reviewing an early draft of the manuscript; Jared Singer for help with LA-ICPMS zircon analysis; and Mark Pecha for assistance with U/Pb zircon analysis. John Aleinikoff and Robert Darling are thanked for providing constructive reviews of the manuscript. 


\section{References}

Armstrong, R., and Stump, E. 1971. Additional K-Ar dates, White Mountain Magma Series, New England. American Journal of Science 270: 331-333.

Bailey, D.G., and Lupulescu, M.V. 2015. Spatial, temporal, mineralogical, and compositional variations in Mesozoic kimberlitic magmatism in New York State. Lithos 212-215: 298310.

Belousova, E.A., Griffen, W.L., O'Reilly, S.Y., and Fisher, N.I. 2002. Igneous zircon: trace element composition as an indicator of source rock type. Contributions to Mineralogy and Petrology 143: 602-622.

Beyer, B.J. 1971. A study of the intrusion at Barber Hill, Vermont and related volcanics at Cannon Point, New York. Middlebury College, Middlebury, Vermont.

Buddington, A.F., and Whitcomb, L. 1941. Geology of the Willsboro Qudrangle, New York. New York State Museum Bulletin.

Burke, K. 1977. Are lakes George and Champlain in Neogene graben reactivating early Paleozoic rifts? Abstracts with Programs - Geological Society of America 9(3): 247-248. Conard, P.H. 1983. Geochemistry and petrology of alkaline rocks at Cannon Point, NY and Barber Hill, VT. In Geology, Middlebury College. p. 46.

Cousens, B.L., Prytulak, J., Henry, C.D., Alcazar, A., and Brownrigg, T. 2008. The geology, geochronology, and geochemistry of the Miocene - Pliocene ancestral Cascades arc, northern Sierra Nevada, California and Nevada: The roles of the upper mantle, subducting slab, and the Sierra Nevada lithosphere. Geosphere 4: 829-853.

Crocker, D.E. 1971. A short study of the igneous complexes at Barber Hill, Vermont and Cannon Point, New York. Middlebury College, Middlebury, VT. 
Crough, S.T. 1981. Mesozoic hot spot epeirogeny in eastern North America. Geology 9: 2-6. Eby, G.N. 1985. Age relations, chemistry, and petrogenesis of mafic alkaline dikes from the Monteregian Hills and younger White Mountain igneous provinces. Canadian Journal of Earth Sciences $=$ Revue Canadienne des Sciences de la Terre 22(8): 1103-1111.

Eby, G.N. 1987. The Monteregian Hills and White Mountain alkaline igneous provinces, eastern North America. Geological Society Special Publications 30: 433-447.

Eby, G.N. 2006. Carbonatites to alkali granites; petrogenetic insights from the Chilwa and Monteregian Hills-White Mountain igneous provinces. Abstract Volume [Geological Association of Canada] 31: 45-45.

Eby, G.N., Krueger, H.W., and Creasy, J.W. 1992. Geology, geochronology, and geochemistry of the White Mountain Batholith, New Hampshire. Special Paper Geological Society of America 268: 379-397.

Foland, K.A., and Allen, J.C. 1991. Magma sources for Mesozoic anorogenic granites of the White Mountain magma series, New England, USA. Contributions to Mineralogy and Petrology 109(2): 195-211.

Foland, K.A., and Faul, H. 1977. Ages of the White Mountain intrusives; New Hampshire, Vermont, and Maine, USA. American Journal of Science 277(7): 888-904.

Foland, K.A., Gilbert, L.A., Sebring, C.A., and Chen, J.-F. 1986. (super 40) Ar/ (super 39) Ar ages for plutons of the Monteregian Hills, Quebec; evidence for a single episode of Cretaceous magmatism. Geological Society of America Bulletin 97(8): 966-974.

Gehrels, G.E., Valencia, V., and Ruiz, J. 2008. Enhanced precision, accuracy, efficiency, and spatial resolution of $\mathrm{U}-\mathrm{Pb}$ ages by laser ablation-ulticollector-inductively coupled plasma- 
mass spectrometry. Geochemistry, Geophysics, Geosystems 9. doi:

10.1029/2007GC001805.

Heaman, L.M., and Kjarsgaard, B.A. 2000. Timing of eastern North American kimberlite magmatism; continental extension of the Great Meteor Hotspot track? Earth and Planetary Science Letters 178(3-4): 253-268.

Hubacher, F.A., and Foland, K.A. 1991. (super 40) Ar/ (super 39) Ar ages for Cretaceous intrusions of the White Mountain magma series, northern New England, and their tectonic implications. Abstracts with Programs - Geological Society of America 23(1): 47-47.

Landoll, J.D., and Foland, K.A. 1996. The formation of quartz syenite by crustal contamination at Mont Shefford and other Monteregian complexes, Quebec. Canadian Mineralogist 34, Part 2: 301-324.

Le Bas, M.J., and Streckeisen, A.L. 1991. The IUGS systematics of igneous rocks. Journal of the Geological Society of London 148, Part 5: 825-833.

Leeman, W.P., and Phelps, D.W. 1981. Partitioning of rare earths and other trace elements between sanidine and coexisting volcanic glass. Journal of Geophysical Research $\mathbf{8 6 .}$

Ludwig, K.R. 2008. Isoplot. Berkeley Geochronology Center Special Publication 4: 77. McHone, J.G. 1987. Cretaceous intrusions and rift features in the Champlain Valley of Vermont. Norwich Univ., Dep. Earth Sci. : Northfield, VT, United States, United States. pp. $237-253$.

McHone, J.G. 2012. Composition and age groups of the Central Atlantic magmatic province relative to the Tr-J extinction event. Abstracts with Programs - Geological Society of America 44(2): 55-55. 
McHone, J.G., and Butler, J.R. 1984. Mesozoic igneous provinces of New England and the opening of the North Atlantic Ocean. Geological Society of America Bulletin 95(7): 757765.

McHone, J.G., Hussey, A.M., II, West, D.P., Jr., and Bailey, D.G. 2014. The Christmas Cove Dike of coastal Maine, USA, and regional sources for early Mesozoic flood basalts in northeastern North America. Atlantic Geology 50: 66-90. doi: 10.4138/atlgeol.2014.004.

McHone, J.G., and McHone, N.W. 1999. The New England-Quebec igneous province in western Vermont. Annual Meeting - New England Intercollegiate Geological Conference 91: $341-358$.

Parrish, J.B., and Lavin, P.M. 1982. Tectonic model for kimberlite emplacement in the Appalachian Plateau of Pennsylvania. Geology [Boulder] 10(7): 344-347.

Pearce, J.A., Harris, N.B.W., and Tindle, A.G. 1984. Trace element discrimination diagrams for the tectonic interpretation of granitic rocks. Journal of Petrology 25(4): 956-983.

Roulleau, E., and Stevenson, R.K. 2013. Geochemical and isotopic (Nd-Sr-Hf-Pb) evidence for a lithospheric mantle source in the formation of the alkaline Monteregian Province (Quebec). Canadian Journal of Earth Sciences = Revue Canadienne des Sciences de la Terre 50: 650-666.

Rowe, M.C., Wolff, J.A., Gardner, J.N., Ramos, F.C., Teasdale, R., and Heikoop, C.E. 2007. Development of a continental volcanic field; petrogenesis of pre-caldera intermediate and silicic rocks and origin of the Bandelier magmas, Jemez Mountains (New Mexico, USA). Journal of Petrology 48(11): 2063-2091. doi: 10.1093/petrology/egm050. 
Schlische, R.W., Withjack, M.O., and Olson, P.E. 2003. Relative timing of CAMP, rifting, continental breakup, and basin inversion; tectonic significance. Geophysical Monograph 136: $33-59$.

Sun, S., and McDonough, W.F. 1989. Chemical and isotopic systematics of ocean basalts: implications for mantle compositions and processes. In Magmatism in the Ocean Basins. Edited by A.D. Saunders and M.J. Norry. Geological Society, London. pp. 313-345. 


\section{Figure Captions}

Figure 1. Location of Cannon Point syenite relative to regional distribution of Mesozoic igneous rocks in eastern New York, southern Quebec and northern Vermont and New Hampshire. Boundaries of the New England - Quebec and White Mountain Magma Series provinces from McHone \& Butler (1984). Hillshade base map derived from shuttle radar topography mission (SRTM) data available at http://earthexplorer.usgs.gov.

Figure 2. Field exposure at Cannon Point showing the chilled contacts of the two sills. Sills are separated by an $\sim 50 \mathrm{~cm}$ thick layer of shaly limestone. Total height of exposure in photo $\sim 5 \mathrm{~m}$; hammer length $=28 \mathrm{~cm}$.

Figure 3. Photomicrograph of sill margin showing sanidine phenocrysts with Carlsbad twinning set in a fine-grained, trachytic groundmass (sample CP-9A; XPL).

Figure 4. Total alkalis vs. silica diagram (after Le Bas and Streckeisen (1991)) showing the compositions of the upper and lower sills at Cannon Point. White Mountain Magma Series compositions (Eby et al. 1992) and high silica rocks from the Monteregian Hills (Landoll \& Foland 1996) are shown for comparison.

Figure 5. $\mathrm{La} / \mathrm{Sm}$ and $\mathrm{Ce} / \mathrm{Ta}$ ratios in granitoid rocks from Cannon Point, Monteregian Hills, and the White Mountain Magma Series. 
Figure 6. Chondrite-normalized REE concentrations in: a) whole-rock samples from the upper and lower sills at Cannon Point, and b) average values for each sill and for zircons extracted from the upper sill. Normalizing factors from Sun and McDonough (1989).

Figure 7. Weighted mean plot of concordant $\mathrm{U}-\mathrm{Pb}$ zircon ages for the upper sill at Cannon Point.

Figure 8. Age of Cannon Point syenite shown on a histogram of ages of Monteregian Hills intrusives (from data compiled and available at Système d'information géominière of Québec website: http://sigeom.mines.gouv.qc.ca/signet/classes/I1108 afchCarteIntr?1=a). Age of Barber Hill syenite from Armstrong \& Stump (1971). Ages are from many different analytical techniques over a period of many decades but still serve to illustrate the general pattern of Mesozoic igneous activity in the region.

Figure 9. Effects of alteration on the composition of the Cannon Point syenites: a) LOI versus $\mathrm{CaO}$ concentrations in the two sills showing strong positive correlation reflecting the extent of carbonatization of the samples; b) Sr vs $\mathrm{CaO}$ showing that $\mathrm{Sr}$ concentrations, and presumably $\mathrm{Sr}$ isotopic ratios, are also modified by carbonatization.

Figure 10. Initial Nd and Sr isotopic ratios of the Cannon Point sills compared to those of other Mesozoic granitoid intrusions from the WMMS (Foland and Allen 1991) and the Monteregian Hills (Landoll and Foland 1996). Epsilon Sr and Nd values are relative to present day bulk Earth values. 
Figure 11. Trace element tectonic discrimination diagram for granitoid rocks (after Pearce et al. (1984)). Monteregian Hills data from Landoll and Foland (1996); WMMS data from Eby et al. (1992).

Figure 12. Ocean ridge granite (ORG) normalized element abundance diagrams showing the relative concentrations of incompatible elements in the Cannon Point syenite relative to the concentrations in other high silica igneous rocks: a) Cannon Point syenite trace element profiles compared to silicic igneous rocks from subduction zone settings (Crater Lake and Tuolumne) and continental and oceanic hot spots (Yellowstone and Iceland); b) Cannon Point syenite trace element profiles compared to those of high silica rocks from the White Mountains, the Monteregian Hills, and Valles Caldera. ORG normalizing values from Pearce et al. (1984); Monteregian Hills nordmarkite data from Eby 1985); all other rock suite data downloaded from www.earthchem.org, filtered for igneous rocks with $\mathrm{SiO}_{2}$ concentrations between 65 and 75 wt. percent. 


\section{Appendix 1:}

\section{Detailed methods for U-Pb geochronologic analyses of igneous zircon (Nu HR ICPMS)}

$\mathrm{U}-\mathrm{Pb}$ geochronology of zircons was conducted by laser ablation multicollector inductively coupled plasma mass spectrometry (LA-MC-ICPMS) at the Arizona LaserChron Center following their standard procedure (outlined below, and in Gehrels et al. (2008)). Zircon crystals were extracted from samples by traditional methods of crushing and grinding, followed by separation with a Wilfley table, heavy liquids, and a Frantz magnetic separator. Samples were processed such that all zircons were retained in the final heavy mineral fraction. A split of these grains (generally 50-100 grains) were handpicked with the use of a binocular microscope and were not sieved prior to picking. The grains ranged in size from 50-200 microns; most were anhedral fragments. The selected grains were incorporated into a 1" epoxy mount together with fragments of the Laserchron center's Sri Lanka standard zircon. The mounts were sanded down to a depth of $\sim 20$ microns, polished, imaged using the cathodoluminescence mode of a scanning electron microcscope, and cleaned prior to isotopic analysis.

The analyses involved ablation of zircon with a Photon Machines Analyte G2 Excimer laser using a spot diameter of 30 microns. The ablation pit was $\sim 15$ microns in depth. The ablated material was carried in helium into the plasma source of a Nu HR ICPMS, which is equipped with a flight tube of sufficient width that $\mathrm{U}, \mathrm{Th}$, and $\mathrm{Pb}$ isotopes are measured simultaneously. All measurements were made in static mode, using Faraday detectors with $3 \times 10^{11} \mathrm{ohm}$ resistors for ${ }^{238} \mathrm{U},{ }^{232} \mathrm{Th},{ }^{208} \mathrm{~Pb}-{ }^{206} \mathrm{~Pb}$, and discrete dynode ion counters for ${ }^{204} \mathrm{~Pb}$ and ${ }^{202} \mathrm{Hg}$. Ion yields were $\sim 0.8 \mathrm{mv}$ per ppm. Each analysis consisted of one 15 -second 
integration on peaks with the laser off (for backgrounds), 15 one-second integrations with the laser firing, and a 30 second delay to purge the previous sample and prepare for the next analysis.

For each analysis, the errors in determining ${ }^{206} \mathrm{~Pb} /{ }^{238} \mathrm{U}$ and ${ }^{206} \mathrm{~Pb} /{ }^{204} \mathrm{~Pb}$ result in a measurement error of $\sim 1-2 \%$ (at 2-sigma level) in the ${ }^{206} \mathrm{~Pb} /{ }^{238} \mathrm{U}$ age. The errors in measurement of ${ }^{207} \mathrm{~Pb} /{ }^{206} \mathrm{~Pb}$ and ${ }^{206} \mathrm{~Pb} /{ }^{204} \mathrm{~Pb}$ also result in $\sim 1-2 \%$ (at 2-sigma level) uncertainty in age for grains that are $>1.0 \mathrm{Ga}$, but are substantially larger for younger grains due to low intensity of the ${ }^{207} \mathrm{~Pb}$ signal. For most analyses, the cross-over in precision of ${ }^{206} \mathrm{~Pb} /{ }^{238} \mathrm{U}$ and ${ }^{207} \mathrm{~Pb} /{ }^{206} \mathrm{~Pb}$ ages occurs at $\sim 1.0 \mathrm{Ga}$.

${ }^{204} \mathrm{Hg}$ interference with ${ }^{204} \mathrm{~Pb}$ is accounted for measurement of ${ }^{202} \mathrm{Hg}$ during laser ablation and subtraction of ${ }^{204} \mathrm{Hg}$ according to the natural ${ }^{202} \mathrm{Hg} /{ }^{204} \mathrm{Hg}$ of 4.35 . This $\mathrm{Hg}$ is correction is not significant for most analyses because our $\mathrm{Hg}$ backgrounds are low (generally $150 \mathrm{cps}$ at mass 204).

Common $\mathrm{Pb}$ correction is accomplished by using the $\mathrm{Hg}$-corrected ${ }^{204} \mathrm{~Pb}$ and assuming an initial $\mathrm{Pb}$ composition from Stacey and Kramers (1975). Uncertainties of 1.5 for ${ }^{206} \mathrm{~Pb} /{ }^{204} \mathrm{~Pb}$ and 0.3 for ${ }^{207} \mathrm{~Pb} /{ }^{204} \mathrm{~Pb}$ are applied to these compositional values based on the variation in $\mathrm{Pb}$ isotopic composition in modern crystalline rocks.

Inter-element fractionation of $\mathrm{Pb} / \mathrm{U}$ is generally $\sim 5 \%$, whereas apparent fractionation of $\mathrm{Pb}$ isotopes is generally $<0.2 \%$. In-run analysis of fragments of a large zircon crystal (generally every fifth measurement) with known age of 563.5 $\pm 3.2 \mathrm{Ma}$ (2-sigma error) is used to correct for this fractionation. The uncertainty resulting from the calibration correction is generally $1-2 \%$ (2-sigma) for both ${ }^{206} \mathrm{~Pb} /{ }^{207} \mathrm{~Pb}$ and ${ }^{206} \mathrm{~Pb} /{ }^{238} \mathrm{U}$ ages. A comprehensive 
review of uncertainty in LA-ICP-MS U-(Th-)Pb geochronology is available in Horstwood et al. (2016).

Concentrations of U and Th are calibrated relative to the LaserChron center's Sri Lanka zircon, which contains $\sim 518 \mathrm{ppm}$ of $\mathrm{U}$ and $68 \mathrm{ppm}$ Th, and are accurate to $\sim 20 \%$.

Uncertainties reported are at the 1-sigma level, and include only measurement errors. Analyses that are $>20 \%$ discordant (by comparison of ${ }^{206} \mathrm{~Pb} /{ }^{238} \mathrm{U}$ and ${ }^{207} \mathrm{~Pb} /{ }^{206} \mathrm{~Pb}$ ages) or $>5 \%$ reverse discordant are discarded. The resulting interpreted ages are shown on $\mathrm{Pb} * / \mathrm{U}$ concordia diagrams and weighted mean diagrams using the routines in Isoplot (Ludwig 2008). The weighted mean diagrams show the weighted mean (weighting according to the square of the internal uncertainties), the uncertainty of the weighted mean, the external (systematic) uncertainty that corresponds to the ages used, the final uncertainty of the age (determined by quadratic addition of the weighted mean and external uncertainties), and the MSWD of the data set.

\section{References}

Gehrels, G.E., Valencia, V., and Ruiz, J. 2008. Enhanced precision, accuracy, efficiency, and spatial resolution of $\mathrm{U}-\mathrm{Pb}$ ages by laser ablation-ulticollector-inductively coupled plasmamass spectrometry. Geochemistry, Geophysics, Geosystems 9, doi:

\subsection{9/2007GC001805.}

Horstwood, M.S.A., Košler, J., Gehrels, G., Jackson, S.E., McLean, N.M., Paton, C., Pearson, N.J., Sircombe, K., Sylvester, P., Vermeesch, P., Bowring, J.F., Condon, D.J., and Schoene, B. 2016. Community-Derived Standards for LA-ICP-MS U-(Th-)Pb Geochronology - Uncertainty Propagation, Age Interpretation and Data Reporting. 
Geostandards and Geoanalytical Research, 40(3): 311-332. doi: 10.1111/j.1751908X.2016.00379.x.

Ludwig, K.R. 2008. Isoplot. Berkeley Geochronology Center Special Publication 4: 77.

Stacey, J.S., and Kramers, J.D. 1975. Approximation of terrestrial lead isotope evolution by a two-stage model. Earth and Planetary Science Letters 26: 207-221. 


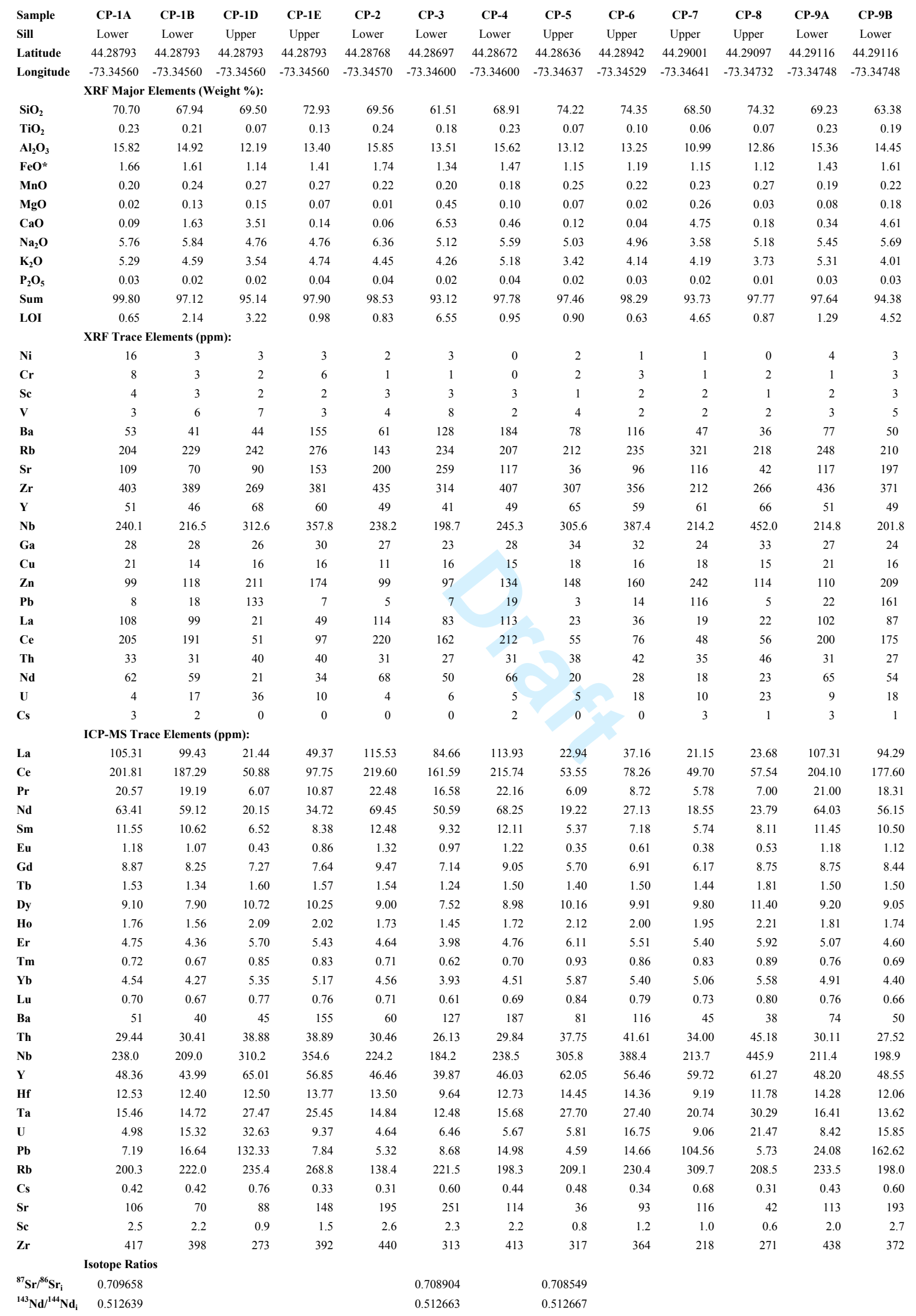


Table 2. U-Pb zircon analyses of the Cannon Point syenite (upper sill).

\begin{tabular}{|c|c|c|c|c|c|c|c|c|c|c|c|c|c|c|c|c|c|c|}
\hline Spot & $\begin{array}{c}\mathbf{U} \\
(\mathrm{ppm})\end{array}$ & $\begin{array}{l}{ }^{206} \mathrm{~Pb} / \\
{ }^{204} \mathrm{~Pb}\end{array}$ & U/Th & $\begin{array}{l}{ }^{206} \mathrm{~Pb}^{* /} \\
{ }^{207} \mathrm{~Pb}^{*}\end{array}$ & $\begin{array}{c} \pm \\
(\%)\end{array}$ & 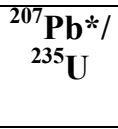 & $\begin{array}{c} \pm \\
(\%)\end{array}$ & $\begin{array}{c}\mathbf{2}^{06} \mathrm{~Pb}^{* /} \\
{ }^{238} \mathrm{U}\end{array}$ & $\begin{array}{c} \pm \\
(\%)\end{array}$ & $\begin{array}{l}\text { Error } \\
\text { Corr. }\end{array}$ & $\begin{array}{c}{ }^{206} \mathbf{P b}^{* /} \\
{ }^{238} \mathbf{U}^{*}\end{array}$ & $\begin{array}{c} \pm \\
(\mathrm{Ma})\end{array}$ & $\begin{array}{c}{ }^{207} \mathbf{P b}^{* /} \\
{ }^{235} \mathbf{U}^{*}\end{array}$ & $\begin{array}{c} \pm \\
(\mathrm{Ma})\end{array}$ & $\begin{array}{c}{ }^{206} \mathrm{~Pb}^{* /} \\
{ }^{207} \mathrm{~Pb}^{*}\end{array}$ & $\begin{array}{c} \pm \\
(\mathrm{Ma})\end{array}$ & $\begin{array}{c}\text { Best } \\
\text { Age } \\
(\mathrm{Ma}) \\
\end{array}$ & $\begin{array}{c} \pm \\
(\mathrm{Ma})\end{array}$ \\
\hline 13 & 26 & 3298 & 0.8 & 21.5331 & 6.9 & 0.1282 & 7.2 & 0.0200 & 2.2 & 0.30 & 127.8 & 2.7 & 122.5 & 8.3 & 20.5 & 165.6 & 127.8 & 2.7 \\
\hline 24 & 29 & 4920 & 0.6 & 20.5920 & 5.3 & 0.1344 & 6.0 & 0.0201 & 2.8 & 0.47 & 128.1 & 3.6 & 128.0 & 7.2 & 126.8 & 124.9 & 128.1 & 3.6 \\
\hline 21 & 22 & 1908 & 0.6 & 25.1244 & 6.9 & 0.1103 & 7.5 & 0.0201 & 3.0 & 0.40 & 128.3 & 3.8 & 106.3 & 7.6 & 363.8 & 178.9 & 128.3 & 3.8 \\
\hline 30 & 25 & 3383 & 0.8 & 23.5867 & 7.4 & 0.1180 & 7.9 & 0.0202 & 2.6 & 0.33 & 128.8 & 3.3 & 113.3 & 8.4 & 202.9 & 186.5 & 128.8 & 3.3 \\
\hline 10 & 43 & 31195 & 0.5 & 21.0623 & 6.0 & 0.1326 & 6.4 & 0.0203 & 2.3 & 0.36 & 129.2 & 3.0 & 126.4 & 7.6 & 73.4 & 141.9 & 129.2 & 3.0 \\
\hline 23 & 20 & 1303 & 0.8 & 23.5262 & 8.4 & 0.1188 & 9.1 & 0.0203 & 3.4 & 0.38 & 129.4 & 4.4 & 114.0 & 9.8 & 196.4 & 211.0 & 129.4 & 4.4 \\
\hline 17 & 29 & 5396 & 0.6 & 22.0789 & 7.4 & 0.1267 & 7.7 & 0.0203 & 2.2 & 0.28 & 129.5 & 2.8 & 121.1 & 8.8 & 39.9 & 178.8 & 129.5 & 2.8 \\
\hline 18 & 29 & 2319 & 0.7 & 21.7402 & 6.7 & 0.1288 & 7.3 & 0.0203 & 2.9 & 0.39 & 129.6 & 3.7 & 123.0 & 8.4 & 2.5 & 161.6 & 129.6 & 3.7 \\
\hline 25 & 20 & 3788 & 0.8 & 21.1757 & 7.3 & 0.1325 & 8.0 & 0.0203 & 3.3 & 0.41 & 129.8 & 4.2 & 126.3 & 9.5 & 60.6 & 174.3 & 129.8 & 4.2 \\
\hline 5 & 24 & 16916 & 0.7 & 18.9864 & 7.0 & 0.1484 & 7.5 & 0.0204 & 2.7 & 0.36 & 130.4 & 3.4 & 140.5 & 9.8 & 314.6 & 159.2 & 130.4 & 3.4 \\
\hline 14 & 31 & 6736 & 0.6 & 19.0394 & 5.9 & 0.1480 & 6.3 & 0.0204 & 2.1 & 0.33 & 130.4 & 2.7 & 140.2 & 8.2 & 308.2 & 134.9 & 130.4 & 2.7 \\
\hline 32 & 30 & 9326 & 0.6 & 19.1641 & 7.4 & 0.1471 & 8.1 & 0.0204 & 3.4 & 0.41 & 130.5 & 4.3 & 139.3 & 10.6 & 293.4 & 169.4 & 130.5 & 4.3 \\
\hline 11 & 19 & 2214 & 0.8 & 20.5090 & 7.8 & 0.1376 & 8.1 & 0.0205 & 2.3 & 0.29 & 130.6 & 3.0 & 130.9 & 9.9 & 136.2 & 182.4 & 130.6 & 3.0 \\
\hline 2 & 29 & 3169 & 0.6 & 25.7542 & 6.9 & 0.1096 & 7.2 & 0.0205 & 2.1 & 0.30 & 130.7 & 2.7 & 105.6 & 7.2 & 428.3 & 180.3 & 130.7 & 2.7 \\
\hline 33 & 22 & 2553 & 0.6 & 21.6023 & 7.0 & 0.1308 & 7.5 & 0.0205 & 2.6 & 0.35 & 130.7 & 3.4 & 124.8 & 8.8 & 12.8 & 168.2 & 130.7 & 3.4 \\
\hline 31 & 24 & 3830 & 0.8 & 20.7835 & 8.1 & 0.1361 & 8.6 & 0.0205 & 2.9 & 0.33 & 130.9 & 3.7 & 129.5 & 10.5 & 104.9 & 192.4 & 130.9 & 3.7 \\
\hline 19 & 19 & 1665 & 0.8 & 23.1735 & 9.0 & 0.1225 & 9.8 & 0.0206 & 3.9 & 0.40 & 131.3 & 5.0 & 117.3 & 10.8 & 158.8 & 223.7 & 131.3 & 5.0 \\
\hline 26 & 23 & 50756 & 0.7 & 21.5654 & 6.8 & 0.1316 & 7.4 & 0.0206 & 2.9 & 0.39 & 131.4 & 3.7 & 125.6 & 8.7 & 16.9 & 163.2 & 131.4 & 3.7 \\
\hline 27 & 20 & 3484 & 0.8 & 19.4769 & 8.8 & 0.1461 & 9.5 & 0.0206 & 3.4 & 0.36 & 131.7 & 4.4 & 138.5 & 12.3 & 256.2 & 203.4 & 131.7 & 4.4 \\
\hline 22 & 27 & 3927 & 1.0 & 23.9905 & 6.2 & 0.1190 & 7.0 & 0.0207 & 3.1 & 0.44 & 132.2 & 4.0 & 114.2 & 7.5 & 245.6 & 158.0 & 132.2 & 4.0 \\
\hline 9 & 20 & 6093 & 0.8 & 19.3636 & 9.2 & 0.1478 & 9.6 & 0.0207 & 2.8 & 0.30 & 132.4 & 3.7 & 139.9 & 12.6 & 269.6 & 210.6 & 132.4 & 3.7 \\
\hline 29 & 114 & 38544 & 0.6 & 20.6536 & 3.9 & 0.1387 & 4.3 & 0.0208 & 1.8 & 0.43 & 132.6 & 2.4 & 131.9 & 5.3 & 119.7 & 92.0 & 132.6 & 2.4 \\
\hline 12 & 23 & 4383 & 0.6 & 19.3791 & 8.3 & 0.1479 & 8.7 & 0.0208 & 2.6 & 0.30 & 132.6 & 3.4 & 140.0 & 11.4 & 267.8 & 191.2 & 132.6 & 3.4 \\
\hline 7 & 49 & 11726 & 0.5 & 22.9095 & 4.9 & 0.1251 & 5.3 & 0.0208 & 2.0 & 0.38 & 132.6 & 2.7 & 119.7 & 6.0 & 130.4 & 120.9 & 132.6 & 2.7 \\
\hline 16 & 28 & 4424 & 0.6 & 19.1613 & 7.5 & 0.1499 & 7.9 & 0.0208 & 2.4 & 0.30 & 132.9 & 3.1 & 141.8 & 10.5 & 293.7 & 172.6 & 132.9 & 3.1 \\
\hline 1 & 27 & 8558 & 0.7 & 21.6582 & 6.4 & 0.1329 & 6.9 & 0.0209 & 2.5 & 0.37 & 133.2 & 3.4 & 126.7 & 8.2 & 6.6 & 154.8 & 133.2 & 3.4 \\
\hline 20 & 30 & 5994 & 0.8 & 12.1654 & 13.0 & 0.2369 & 13.2 & 0.0209 & 2.3 & 0.18 & 133.4 & 3.1 & 215.9 & 25.7 & 1250.3 & 255.1 & 133.4 & 3.1 \\
\hline 15 & 20 & 15204 & 0.8 & 22.3856 & 6.8 & 0.1296 & 7.5 & 0.0210 & 3.3 & 0.44 & 134.2 & 4.3 & 123.7 & 8.8 & 73.5 & 165.5 & 134.2 & 4.3 \\
\hline 4 & 23 & 6615 & 0.8 & 21.1002 & 6.8 & 0.1398 & 7.2 & 0.0214 & 2.5 & 0.34 & 136.4 & 3.3 & 132.8 & 9.0 & 69.1 & 161.7 & 136.4 & 3.3 \\
\hline
\end{tabular}


Notes:

1. Analyses with $>10 \%$ uncertainty (1-sigma) in ${ }^{206} \mathrm{~Pb} /{ }^{238} \mathrm{U}$ age are not included.

2. Analyses with $>10 \%$ uncertainty ( 1 -sigma) in ${ }^{206} \mathrm{~Pb} /{ }^{207} \mathrm{~Pb}$ age are not included, unless ${ }^{206} \mathrm{~Pb} /{ }^{238} \mathrm{U}$ age is $<500 \mathrm{Ma}$.

3. Best age is determined from ${ }^{206} \mathrm{~Pb} /{ }^{238} \mathrm{U}$ age for analyses with ${ }^{206} \mathrm{~Pb} /{ }^{238} \mathrm{U}$ age $<1000 \mathrm{Ma}$ and from ${ }^{206} \mathrm{~Pb} /{ }^{207} \mathrm{~Pb}$ age for analyses with ${ }^{206} \mathrm{~Pb} /{ }^{238} \mathrm{U}$ age $>1000 \mathrm{Ma}$.

4. Concordance is based on ${ }^{206} \mathrm{~Pb} /{ }^{238} \mathrm{U}$ age $/{ }^{206} \mathrm{~Pb} /{ }^{207} \mathrm{~Pb}$ age. Value is not reported for ${ }^{206} \mathrm{~Pb} /{ }^{238} \mathrm{U}$ ages $<500 \mathrm{Ma}$ because of large uncertainty in ${ }^{206} \mathrm{~Pb} /{ }^{207} \mathrm{~Pb}$ age.

5. Analyses with ${ }^{206} \mathrm{~Pb} /{ }^{238} \mathrm{U}$ age $>500 \mathrm{Ma}$ and with $>20 \%$ discordance $(<80 \%$ concordance $)$ are not included.

6. Analyses with ${ }^{206} \mathrm{~Pb} /{ }^{238} \mathrm{U}$ age $>500 \mathrm{Ma}$ and with $>5 \%$ reverse discordance $(<105 \%$ concordance $)$ are not included.

7. All uncertainties are reported at the 1-sigma level, and include only measurement errors.

8. Systematic errors are as follows (at 2-sigma level): [sample 1: $\left.2.5 \%\left({ }^{206} \mathrm{~Pb} /{ }^{238} \mathrm{U}\right) \& 1.4 \%\left({ }^{206} \mathrm{~Pb} /{ }^{207} \mathrm{~Pb}\right)\right]$. These values are reported on cells $\mathrm{U} 1$ and $\mathrm{W} 1 \mathrm{of}$ NUagecalc.

9. Analyses conducted by LA-MC-ICPMS, as described by Gehrels et al. (2008).

10. U concentration and U/Th are calibrated relative to Sri Lanka zircon standard and are accurate to $\sim 20 \%$.

11. Common $\mathrm{Pb}$ correction is from measured ${ }^{204} \mathrm{~Pb}$ with common $\mathrm{Pb}$ composition interpreted from Stacey and Kramers (1975).

12. Common $\mathrm{Pb}$ composition assigned uncertainties of 1.5 for ${ }^{206} \mathrm{~Pb} /{ }^{204} \mathrm{~Pb}, 0.3$ for ${ }^{207} \mathrm{~Pb} /{ }^{204} \mathrm{~Pb}$, and 2.0 for ${ }^{208} \mathrm{~Pb} /{ }^{204} \mathrm{~Pb}$.

13. $\mathrm{U} / \mathrm{Pb}$ and ${ }^{206} \mathrm{~Pb} /{ }^{207} \mathrm{~Pb}$ fractionation is calibrated relative to fragments of a large Sri Lanka zircon of $563.5 \pm 3.2 \mathrm{Ma}$ (2-sigma).

14. $\mathrm{U}$ decay constants and ratios used: ${ }^{235} \mathrm{U}=9.8485 \times 10^{-10},{ }^{238} \mathrm{U}=1.55125 \times 10^{-10},{ }^{238} \mathrm{U} /{ }^{235} \mathrm{U}=137.88$.

15. Weighted mean plot created with Isoplot (Ludwig 2008). 


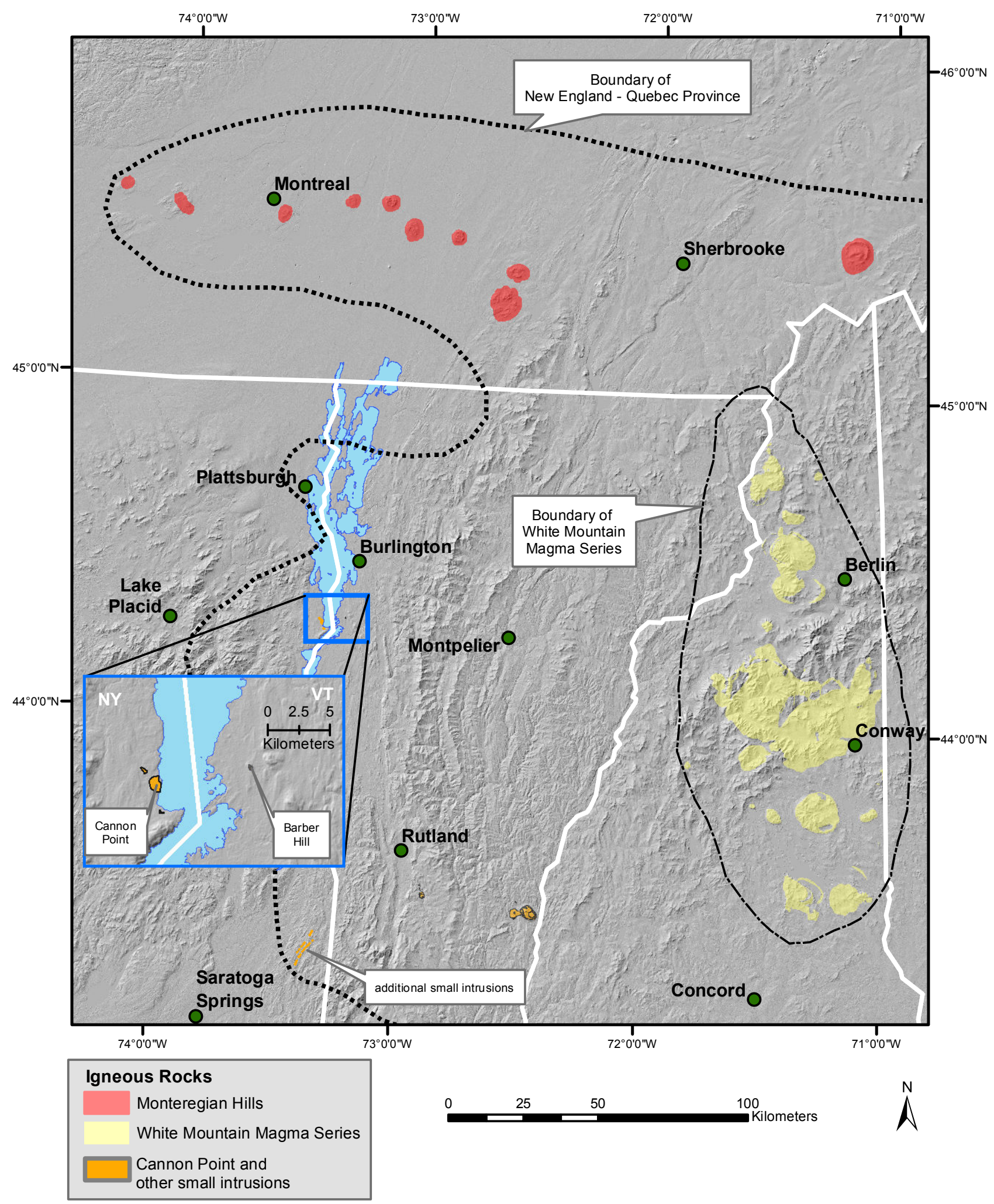


$\left.16 \times x^{5}\right)^{4}$

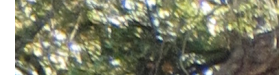

$+4$ 


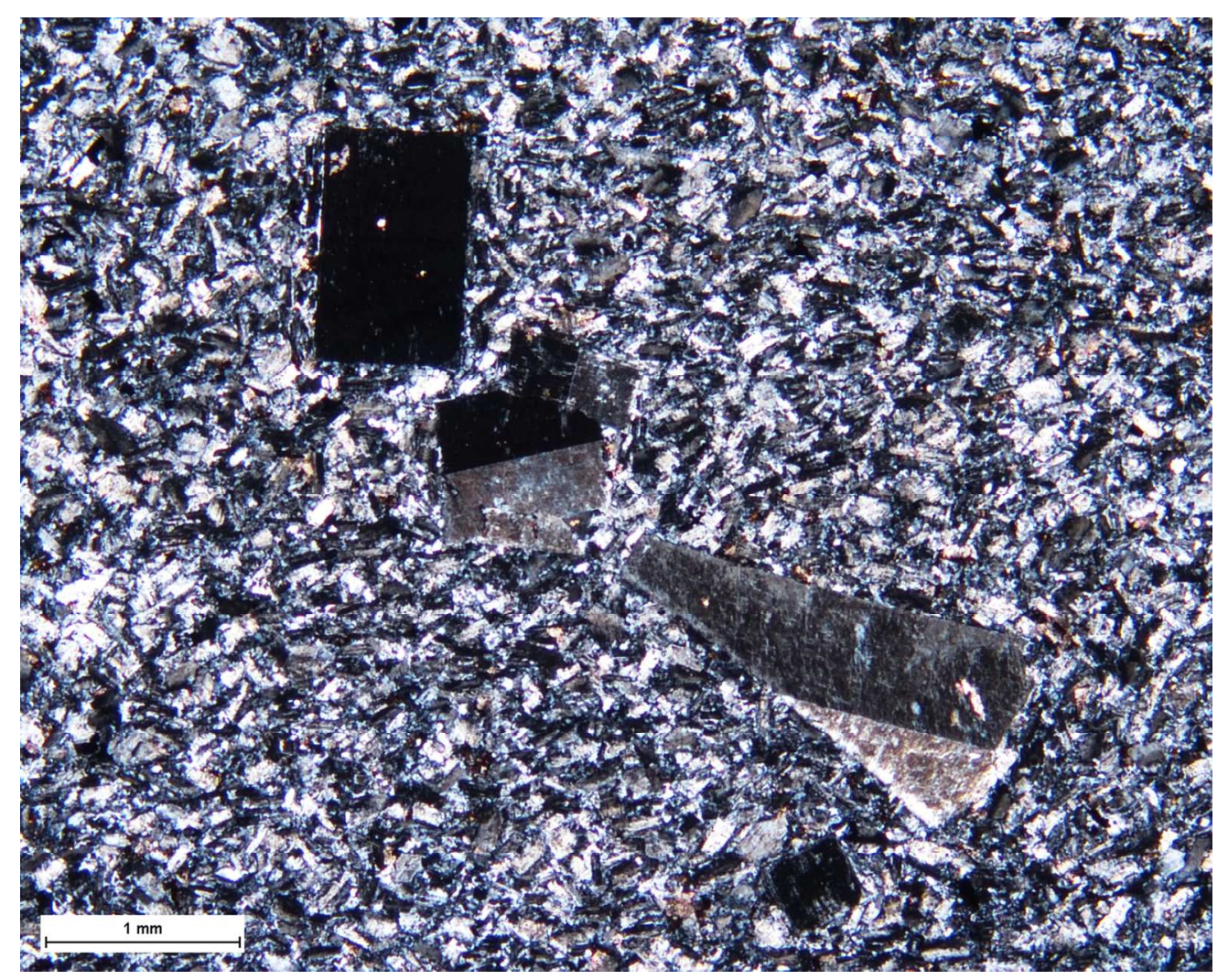

Figure 3. Photomicrograph of sill margin showing sanidine phenocrysts with Carlsbad twinning set in a finegrained, trachytic groundmass (sample CP-9A; XPL).

$152 \times 121 \mathrm{~mm}(300 \times 300 \mathrm{DPI})$ 


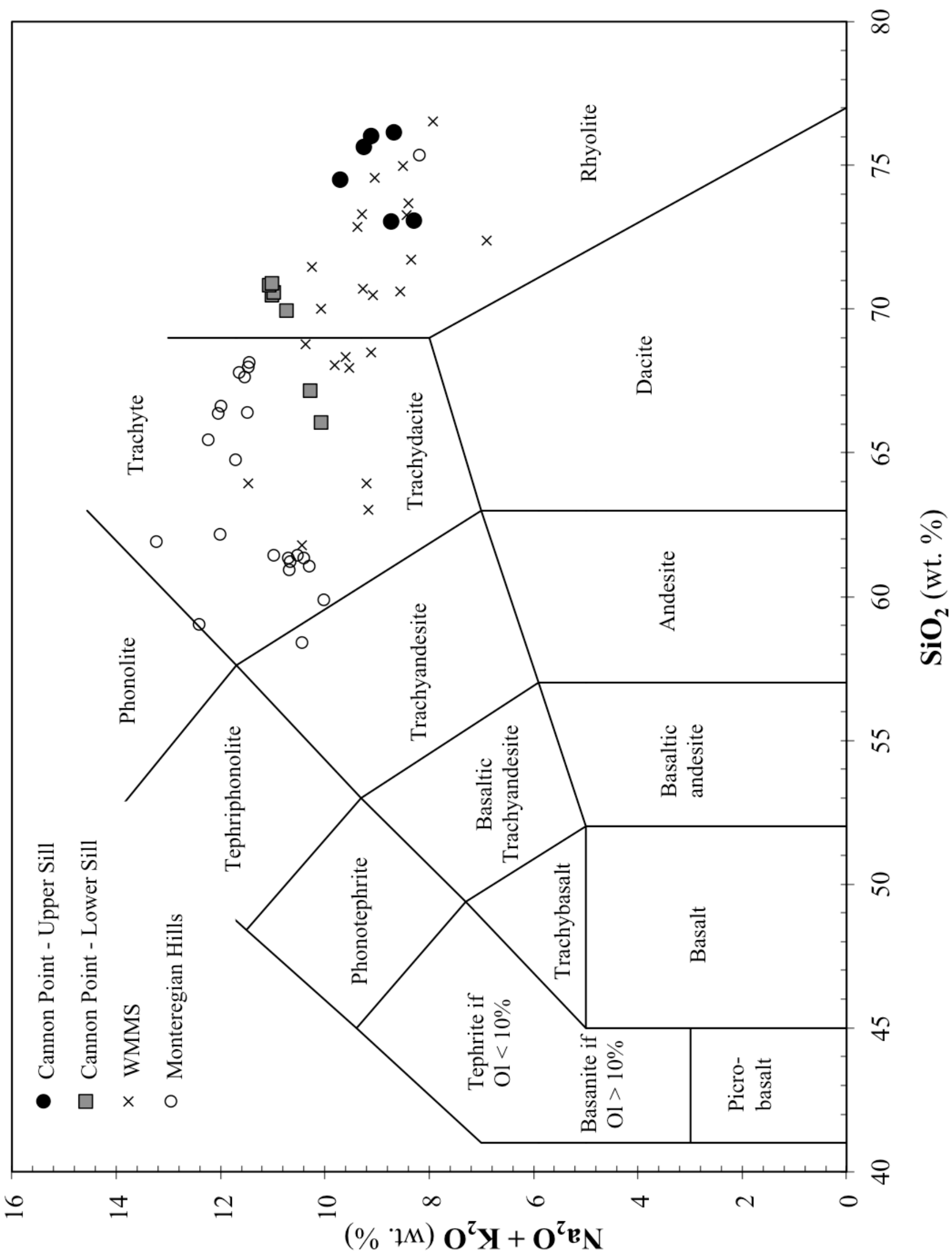




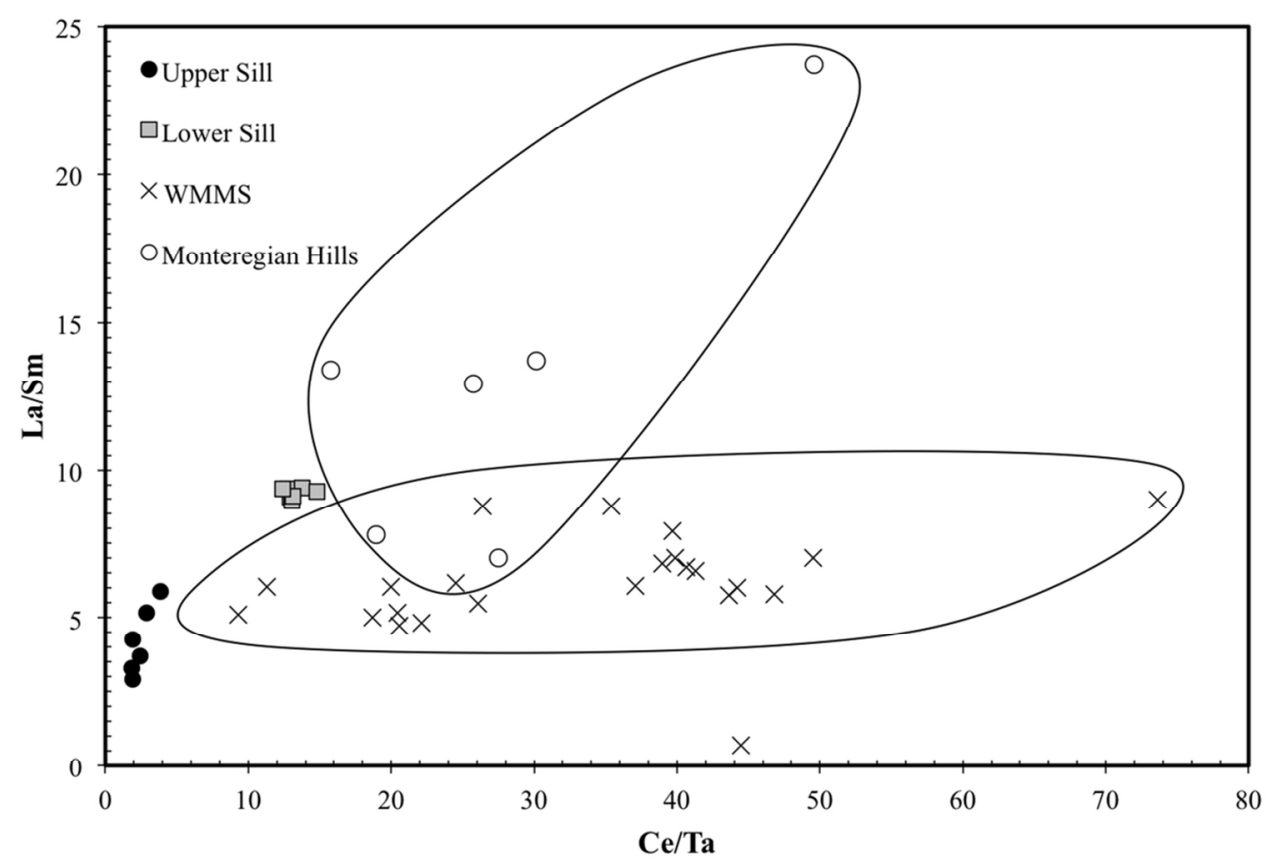

Figure 5. La/Sm and Ce/Ta ratios in granitoid rocks from Cannon Point, Monteregian Hills, and the White Mountain Magma Series.

$103 \times 70 \mathrm{~mm}(300 \times 300$ DPI $)$ 

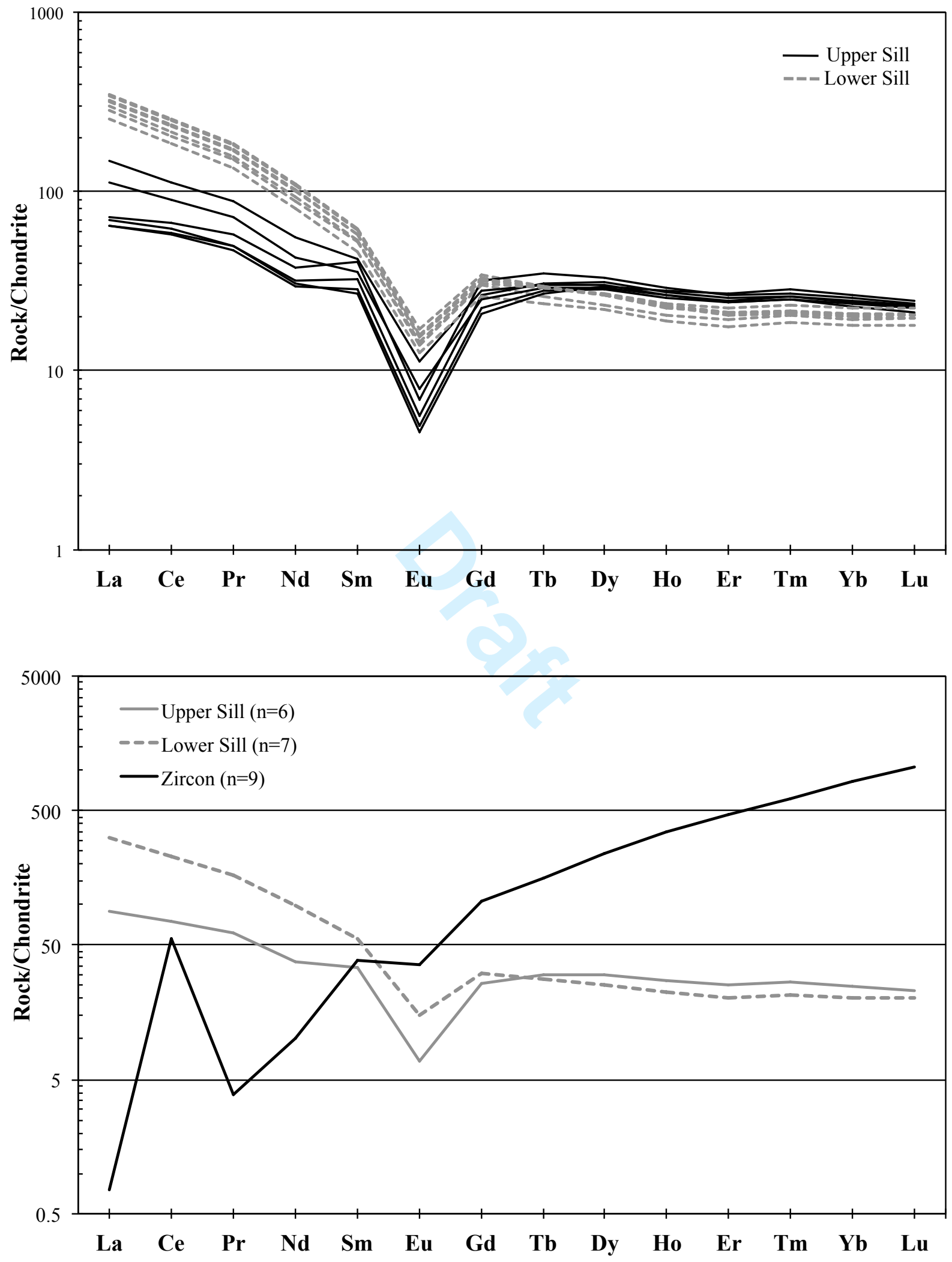


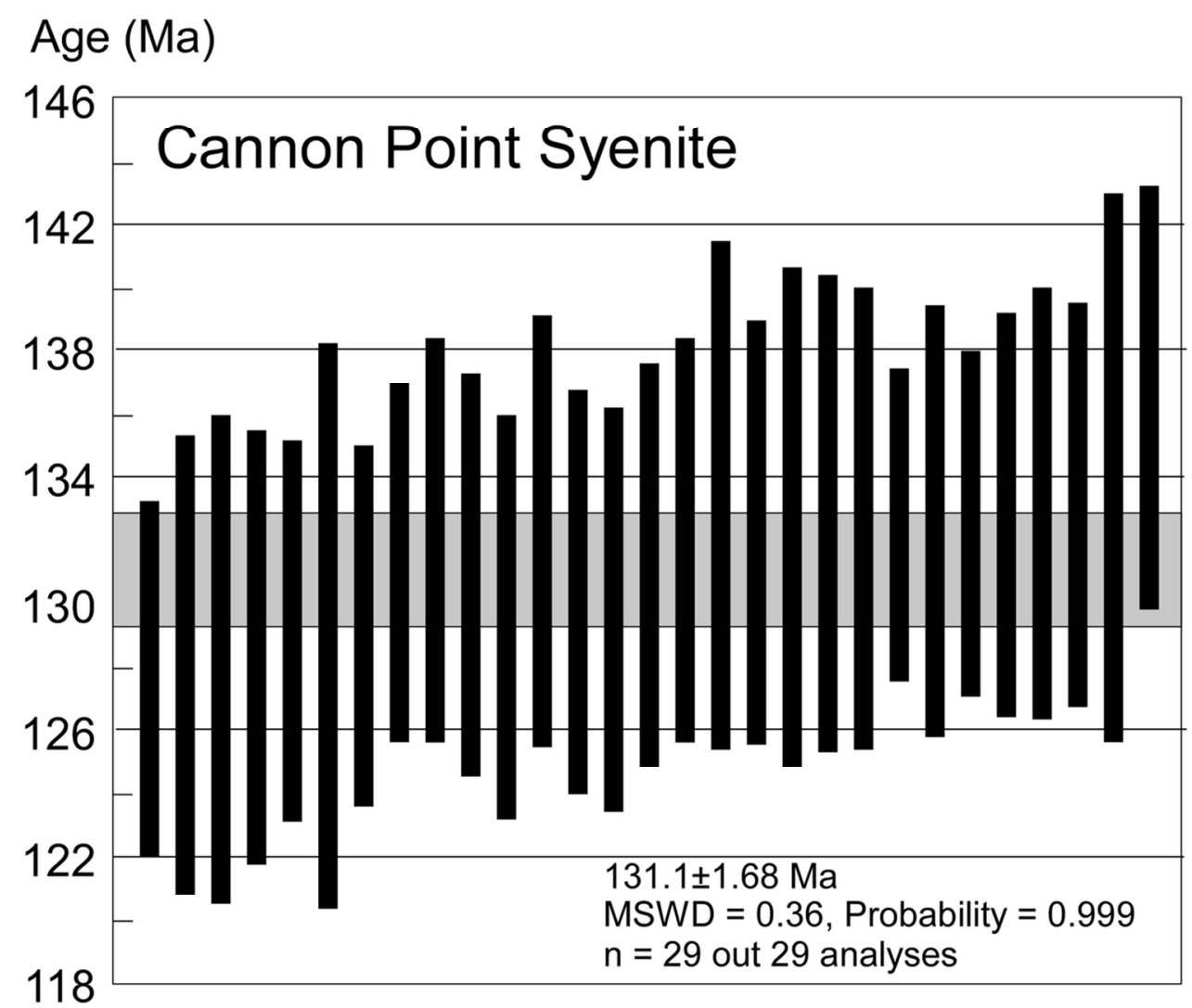

Figure 7. Weighted mean plot of concordant U-Pb zircon ages for the upper sill at Cannon Point. $111 \times 94 \mathrm{~mm}(300 \times 300 \mathrm{DPI})$ 

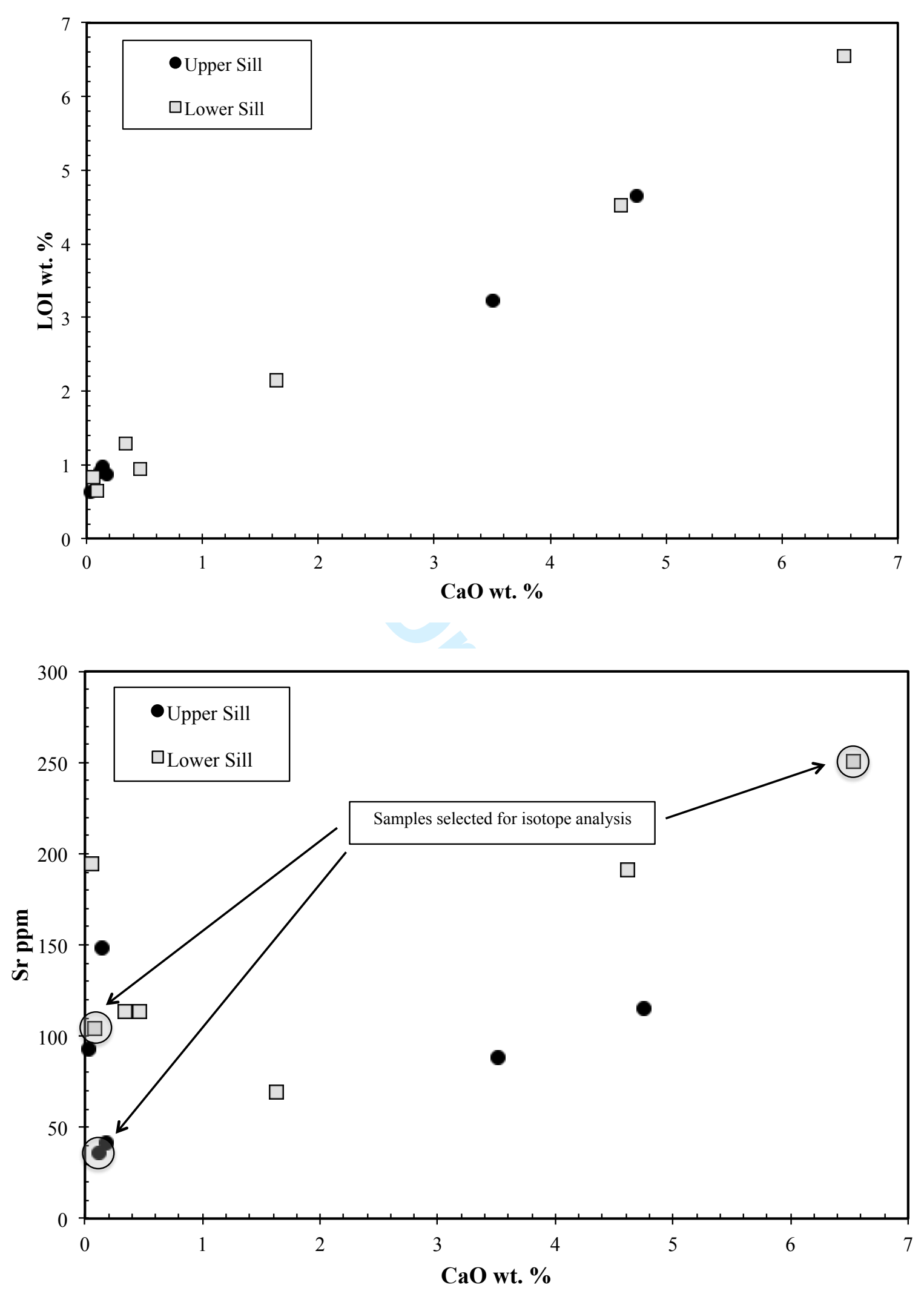


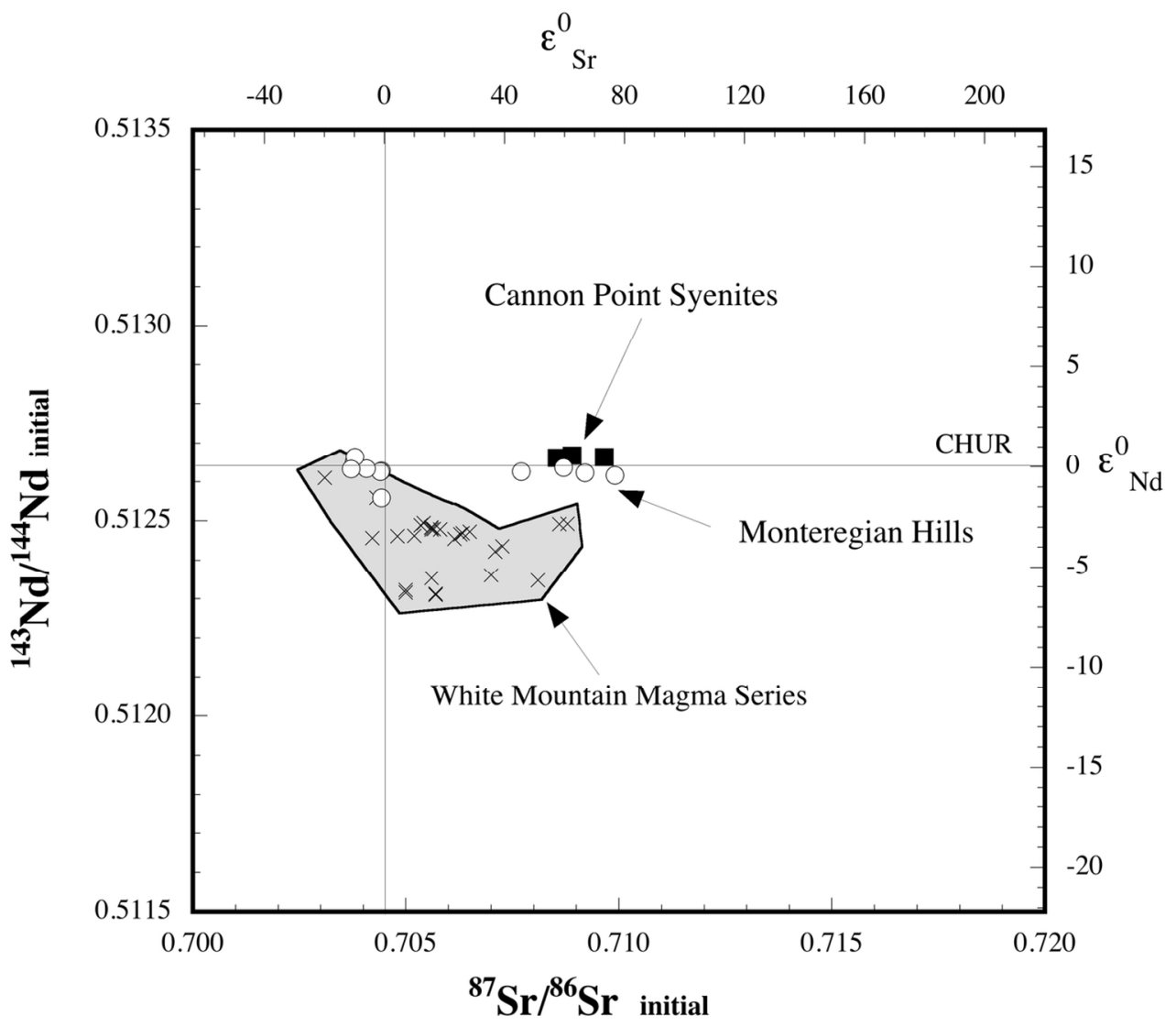

Figure 10. Initial Nd and Sr isotopic ratios of the Cannon Point sills compared to those of other Mesozoic granitoid intrusions from the WMMS (Foland and Allen 1991) and the Monteregian Hills (Landoll and Foland 1996). Epsilon Sr and Nd values are relative to present day bulk Earth values.

$$
123 \times 107 \mathrm{~mm}(300 \times 300 \text { DPI) }
$$




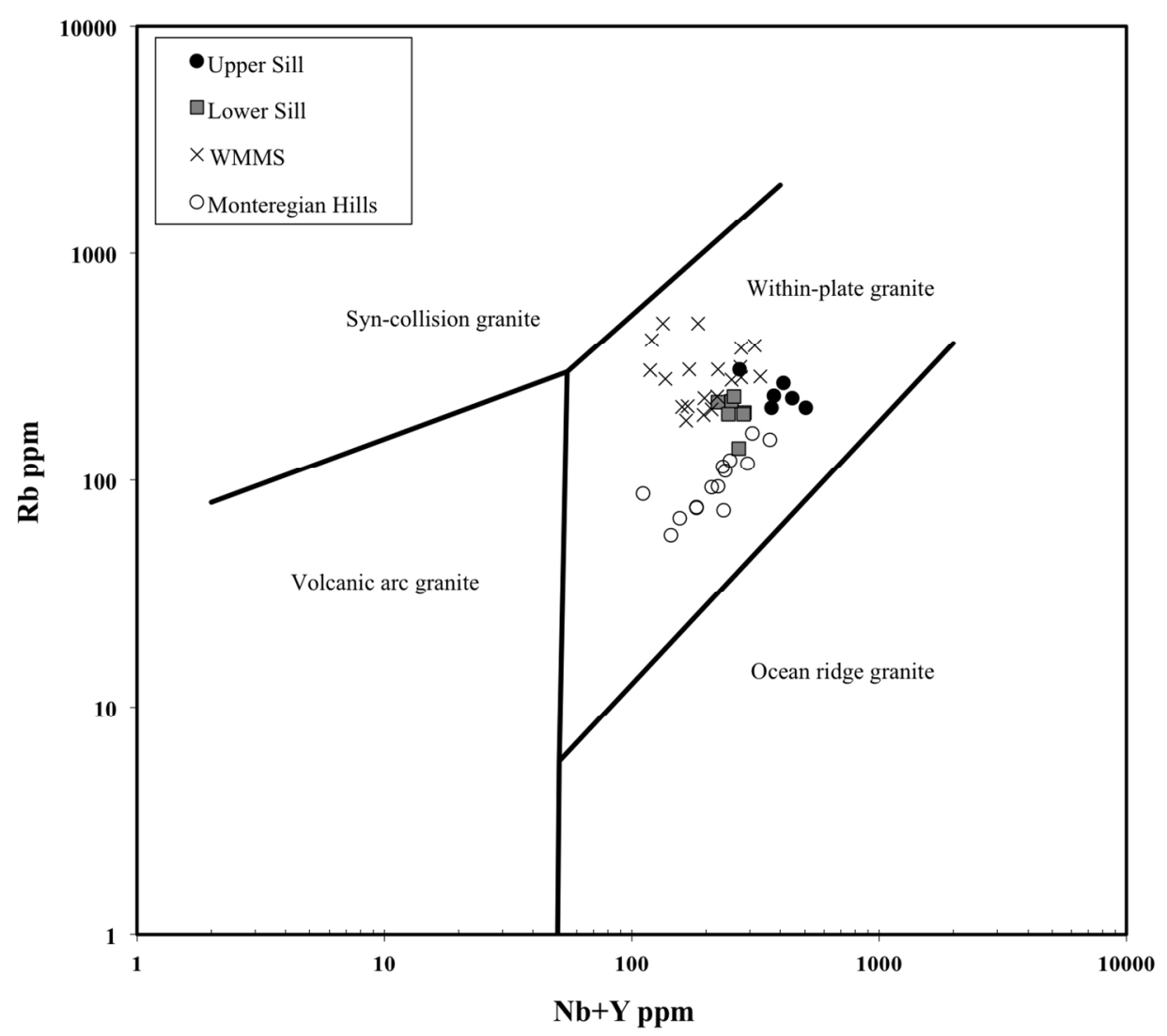

Figure 11. Trace element tectonic discrimination diagram for granitoid rocks (after Pearce et al. (1984)). Monteregian Hills data from Landoll and Foland (1996); WMMS data from Eby et al. (1992). 

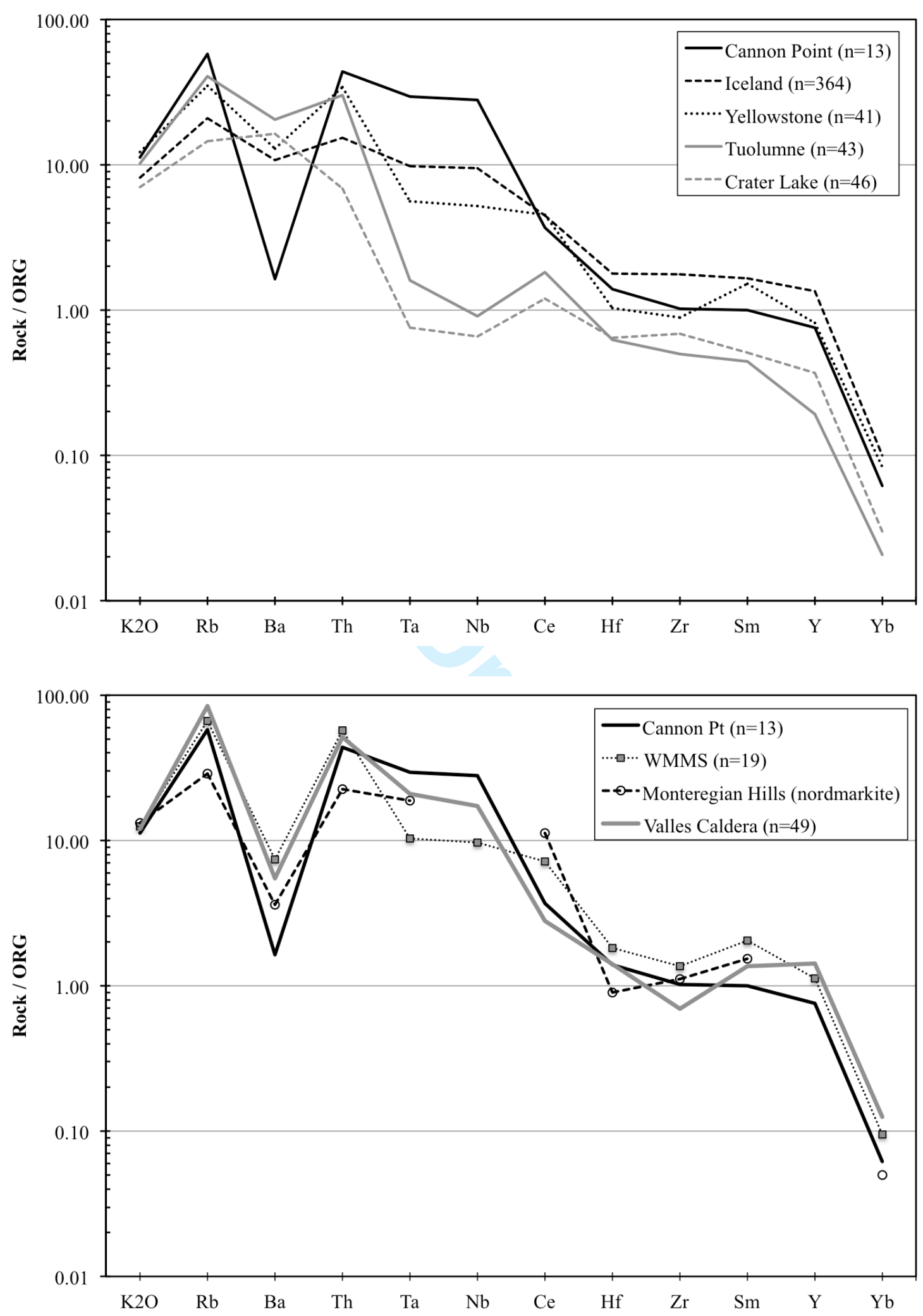